\section{Ascites and Renal Failure in Primary Liver Cell Carcinoma}

Ascites appears in $50-75 \%$ of patients with primary liver cell carcinoma (P.L.C.C. $)^{1}$ but there have been few investigations of its cause. We studied 25 patients with P.L.C.C. and ascites to assess any renal disturbances present.

\section{Patients, Methods, and Results}

Diagnosis was based on histological data, and all except one patient had P.L.C.C. associated with cirrhosis. None received specific treatment for the P.L.C.C. and all died. Liver function was evaluated and renal function studied by determining the creatinine clearance as an index of the glomerular filtration rate (G.F.R.), the sodium, potassium, and urea concentrations in plasma and urine, and plasma and urine osmolality. Ascites was treated by bed rest and a low-salt diet for seven days after admission. Patients who did not lose ascites and body weight were started on distal diuretics (triamterene $300 \mathrm{mg} /$ day or spironolactone $150 \mathrm{mg} /$ day), and if the response was unsatisfactory frusemide $(80 \mathrm{mg} /$ day) was added.

Renal failure was defined as a G.F.R. of below $50 \mathrm{ml} / \mathrm{min}$, and we divided the patients into three groups: (1) 14 patients with progressive renal failure; (2) four patients admitted with good renal function but who developed renal failure while in hospital (their renal failure was identical with that in group 1 , and in none could a cause be found); and (3) seven patients whose good renal function was maintained.

Necropsy of the 13 patients- 10 with renal failure-for whom it was permitted showed normal kidney histology. Liver function tests showed no appreciable differences between patients with renal failure and those without (table). In group 2 the development of renal failure was not accompanied by a worsening liver function.

Only one patient in group $1 \mathrm{had}$ a positive response to diuretic treatment whereas all of group 2 had a good response initially, but the development of renal failure was followed by a fall of diuresis and natriuresis. Response was excellent in group 3, ascites being lost in all cases. All the patients with renal failure died in hospital (mean survival time 14.5 days), whereas those without renal failure were discharged without ascites and survived for a mean of 173 days $(P<0.001)$.

\section{Discussion}

Renal failure is a recognized complication of liver disease. ${ }^{2}$ In 1965, Vesin et $a .^{3}{ }^{3}$ described two patients with cirrhosis of the liver, ascites, and P.L.C.C. with functional renal failure. In our series the incidence of renal failure in P.L.C.C. was $72 \%$, and like cirrhosis and fulminant hepatic failure it carried a poor prognosis. All our patients with renal failure died within 45 days of admission, whereas those without renal failure had a mean survival of six months.

Histologically the kidneys of 10 patients who died with renal failure showed no abnormalities. In all patients with renal failure the urinary sodium concentration was low and the urinary urea concentration and urine:plasma osmolality ratio were relatively high. This suggests that renal tubular function was preserved and that renal failure was functional. ${ }^{4}$ Twenty-four of the patients had cirrhosis, so it could be argued that renal failure was related exclusively to cirrhosis. But the incidence of renal failure was much higher than that reported by Bosch $(17 \cdot 7 \%),{ }^{5}$ suggesting that P.L.C.C. was an important factor.

Ascites in patients with cirrhosis and P.L.C.C. is classically considered to be refractory to diuretics. Nearly a third of our patients had a diuretic response, apparently related exclusively to the degree of renal impairment. The seven patients with good renal function lost ascites, two of them with such simple trearment as bed rest and a lowsalt diet.

Requests for reprints should be addressed to: Dr. A. Mas, Unidad de Hepatologia, Hospital Clinico y Provincial, Casanova 143, Barcelona 11, Spain.

${ }^{1}$ MacDonald, R. A., Archives of Internal Medicine, 1957, 99, 266.

2 Summerskill, W. H. J., Gastroenterology, 1966, 51, 94.

3 Vesin, P., Roberti, A., and Viguié, R., Semaine des Hôpitaux de Paris, $1965,41,1216$

4 Vesin, P., in Aktuelle Probleme der Hepatologia, ed. G. A. Martini, p. 98. Stuttgart, Thieme, 1962.

5 Bosch, J., "Tipos de insuficiencia renal asociados a la cirrosis hepática," M. D. thesis, University of Barcelona, 1973.

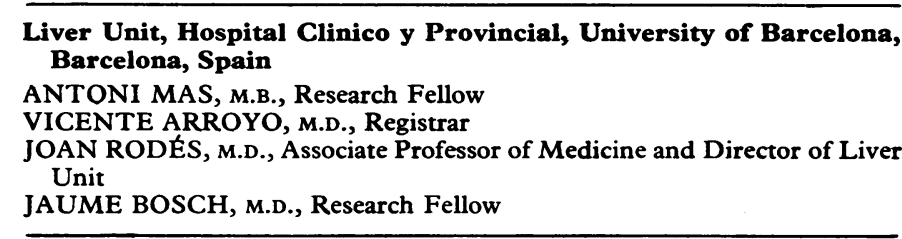

\section{Does the Jet of Acid Emerging Through the Pylorus Determine the Site of Duodenal Bulbar Ulcers?}

Peptic ulcers are usually attributed to either an increase in acid attack or a decrease in mucosal defence. ${ }^{1}$ Duodenal ulcers are characteristically single, discrete, and situated in the middle of the anterior or posterior bulbar wall close to the pylorus. ${ }^{2}$ No constant anatomical features have been identified that would determine the usual sites of ulcer. Animal experiments have indicated that the location of postpyloric peptic ulcers is determined by the jet of acid and gastric contents emerging through the pylorus. ${ }^{3}$ If this is so for humans the usual site of ulceration should lie in the path of the jet emerging through the pylorus. It should also be possible to show that duodenal ulcers or scars lie directly in the path of such a jet.

\section{Methods and Results}

The duodenal bulbar wall was inspected in 200 patients through the pylorus at routine upper gastrointestinal endoscopy. The tip of an end-viewing fibreoptic gastroduodenoscope was manoeuvred close to, and squarely facing, the pylorus. The duodenal wall could be seen through the pylorus. The instrument was then carefully withdrawn, avoiding rotation, while keeping the pylorus centred in the field-of-view to maintain the tip of the instrument as near as possible in the axis of the gastric lumen. Withdrawal was continued until the gastric angulus could be identified providing a point of reference.

Successful views of the duodenal bulb were obtained through the intact pylorus in 162 of the 200 examinations. A straight tunnel was seen in 16

Renal and Hepatic Function in the Three Groups of Patients. Figures are Means \pm S.D.

\begin{tabular}{|c|c|c|c|c|c|c|c|c|c|c|}
\hline \multirow[b]{2}{*}{ Group } & \multirow{2}{*}{$\underset{(\mathrm{ml} / \mathrm{min})}{\mathrm{G} . \mathrm{R} .}$} & \multicolumn{2}{|c|}{ Plasma } & \multicolumn{3}{|c|}{ Urine } & \multirow{2}{*}{$\begin{array}{l}\text { Urine: } \\
\text { Plasma } \\
\text { Osmolality } \\
\text { Ratio }\end{array}$} & \multirow{2}{*}{$\underset{\substack{\text { Serum } \\
\text { Albumin } \\
(\mathbf{g} / 1)}}{ }$} & \multirow{2}{*}{$\underset{\substack{\text { Bilirubin } \\
(\mathrm{mg} / 1)}}{\text { Serum }}$} & \multirow{2}{*}{$\begin{array}{c}\text { Prothrombin } \\
\underset{(\%)}{\text { Time }}\end{array}$} \\
\hline & & $\begin{array}{c}\text { Sodium } \\
(\text { mmol/1) }\end{array}$ & $\underset{(\mathrm{mrea}}{\mathrm{Ur} / \mathrm{l})}$ & $\begin{array}{c}\text { Sodium } \\
(\text { mmol }, 1)\end{array}$ & $\begin{array}{c}\text { Urea } \\
(\text { mmol li) }\end{array}$ & $\begin{array}{l}\text { Volume } \\
24 \mathrm{~h}(\mathrm{ml})\end{array}$ & & & & \\
\hline $\begin{array}{l}1 \\
2\left\{\begin{array}{l}\text { On admission } \\
\text { Before death }\end{array}\right.\end{array}$ & $\begin{array}{l}22.1 \pm 13.4 \\
70.0 \pm 6.2 \\
15.0 \pm 6.3 \\
85.6 \pm 19.6\end{array}$ & $\begin{array}{l}133.8 \pm 6.0 \\
133.7 \pm 1.8 \\
127.5 \pm 8.1 \\
135.3 \pm 5.5\end{array}$ & $\begin{array}{r}18.7 \pm 10.5 \\
5.0 \pm 1.5 \\
24.9 \pm 12.8 \\
4.3 \pm 1.0\end{array}$ & $\begin{array}{r}6 \cdot 6 \pm 6 \cdot 5 \\
38.3 \pm 56 \cdot 6 \\
12.0 \pm 2.7 \\
36.9 \pm 34.8\end{array}$ & $\begin{array}{l}231 \pm 116 \\
329 \pm 227 \\
254 \pm 118 \\
338 \pm 112\end{array}$ & $\begin{array}{r}476 \pm 319 \\
941 \pm 220 \\
182 \pm 42 \\
1320 \pm 228\end{array}$ & $\begin{array}{l}1.64 \pm 0.46 \\
1.91 \pm 0.67 \\
1.79 \pm 0.50 \\
1.75 \pm 0.43\end{array}$ & $\begin{array}{l}30 \pm 6 \\
32 \pm 3 \\
33 \pm 4 \\
30 \pm 3\end{array}$ & $\begin{array}{c}120 \pm 12 \cdot 1 \\
54 \pm 57 \\
65 \pm 54 \\
50 \pm 47\end{array}$ & $\begin{array}{l}65 \pm 15 \\
90 \pm 14 \\
91 \pm 17 \\
84 \pm 15\end{array}$ \\
\hline
\end{tabular}

Conversion: SI to Traditional Units-Plasma sodium: $1 \mathrm{mmol} / 1=1 \mathrm{mEq} / 1$. Plasma urea: $1 \mathrm{mmol} / 1=6 \mathrm{mg} / 100 \mathrm{ml}$. Urinary sodium: $1 \mathrm{mmol} / 1=\mathrm{mEq} / \mathrm{l}$. Urinary urea: 1 $\mathrm{mmol} / \mathrm{l} \approx 0.006 \mathrm{~g} / 100 \mathrm{ml}$ 
patients. In 146 patients the channel curved, making a wall visible which was superior in 19 , posterosuperior in 23 , posterior in 10 , posteroinferior in 12 , inferior in 20 , anteroinferior in 37 , anterior in 16 , and anterosuperior in nine. Duodenal ulcers or scars were identified in 34 patients; they occupied the centre of the visible field in nine and lay superiorly in one, posteriorly in 12 , and anteriorly in 12 .

\section{Discussion}

By centring the pylorus in the field of view the tip of the endoscope was kept close to the axis of the distal stomach. The duodenal wall visible through the pylorus should therefore lie directly in the path of a jet of food and acid leaving the stomach.

The results show that no portion of the duodenal wall was uniquely exposed to, or protected from, emerging gastric contents. Also, the position of duodenal ulcers or scars did not seem to be determined by exposure to a localized jet. The peristaltic mobility of the gastric antrum, pylorus, and duodenal bulb, make it unlikely that a discrete area should be subjected to localized attack. It would also be necessary to invoke two discrete jets to explain the occasional finding of active anterior and posterior bulbar ulcers.

No local anatomical feature has been described that would explain the site of bulbar duodenal ulcers, apart from variation in vascularity and the presence of localized pallor on the anterior duodenal bulbar wall when the gastric antrum is drawn to the left. ${ }^{5}$ An emerging jet cannot be indicted for localized peptic ulceration after the formation of a side-to-side gastroenterostomy; neither can a local anatomical feature be invoked, since the segment of jejunum is selected fortuitously by the surgeon. The site of peptic ulcer, however, may be determined stochastically as the first area at which the balance of defence breaks down. But the frequency with which the ulcer remains solitary is at present inexplicable. Chronic peptic ulceration seems to have the intrinsic characteristics of singularity and discreteness.

${ }^{1}$ Ivy, A. C., Grossman, M. I., and Bachrach, W. H., Peptic Ulcer, p. 765. Philadelphia, Blakiston, 1950.

2 Portis, S. A., and Jaffe, R. H., Fournal of the American Medical Association, 1938, 110, 6 .

3 Oi, M., et al., in Peptic Ulcer, ed. C. J. Pfeiffer, p. 252. Copenhagen, Munksgaard, 1971

${ }^{4}$ Piasecki, C., British fournal of Surgery, 1971, 58, 660.

5 Kirk, R. M., Gut, 1968, 9, 414.

\section{Hyperthyroidism After Cholecystography}

The Jod-Basedow phenomenon-hyperthyroidism induced by iodide -has been recognized for many years in iodine-deficient areas when iodide prophylaxis for goitre has been introduced. In other circumstances iodide has been shown to induce hyperthyroidism. Single exposure to high iodide dose, as in intravenous pyelography, has been followed by hyperthyroidism. ${ }^{1}$ We report here two cases of hyperthyroidism after cholecystography.

\section{Case Reports}

A 56-year-old woman developed attacks of abdominal colic suspicious of biliary tract disease. She had a multinodular goitre but no symptoms or signs of thyroid overactivity. A cholecystogram with $3 \mathrm{~g}$ of sodium ipodate (1800 mg iodine) was performed and showed a non-functioning gall bladder. Within a week she developed palpitations, nervousness, irritability, trembling of her hands, and heat intolerance. When seen four weeks later she had lost $12 \mathrm{~kg}$, despite a good appetite. She was agitated, had lid retraction, warm peripheries with digital tremor, and a tachycardia of $110 / \mathrm{min}$. Her nodular goitre was unchanged. Her serum T-4 was over $300 \mathrm{nmols} / 1(23 \mu \mathrm{g} / 100 \mathrm{ml})$ (normal 58-167 $\mathrm{nmol} / \mathrm{l}(4 \cdot 5-13 \mu \mathrm{g} / 100 \mathrm{ml})$ ). Serum T-3 uptake was 66 (normal range 92-117). ${ }^{131}$ I uptake was $52 \%$ at two hours. Treatment was started with carbimazole, $10 \mathrm{mg}$ thrice daily, and she became clinically euthyroid after four weeks. She continues on this therapy and is awaiting partial thyroidectomy.
A 47-year-old college lecturer consulted his doctor complaining of dyspepsia. A cholecystogram was carried out with $6 \mathrm{~g}$ sodium ipodate (3600 mg iodine). Four days after this he developed trembling of his limbs, increased sweating and heat intolerance, nervousness, and irritability. When seen four weeks later he had lost $4 \mathrm{~kg}$, despite a good appetite. He had a small diffuse midline goitre, warm peripheries with digital tremor, a sinus tachycardia of $110 / \mathrm{min}$, but no eye signs. Serum T-4 was $350 \mathrm{nmols} / 1$ $(27 \mu \mathrm{g} / 100 \mathrm{ml})$ and serum $\mathrm{T}-3$ uptake was 61 . Therapy with carbimazole, 10 mg thrice daily, was started, and after four weeks this was reduced to $5 \mathrm{mg}$ thrice daily when the patient appeared euthyroid. Further reduction of the dose was attempted after three months' therapy, but the signs of hyperthyroidism recurred necessitating return to the previous dose of carbimazole.

\section{Discussion}

The effects of iodide on thyroid function are remarkably diverse. Iodide is essential for thyroid hormone formation. The antithyroid action of iodide is a well-recognized clinical phenomenon in hyperthyroidism, though the normal thyroid gland appears to be insensitive to this antithyroid action of iodide. This may be related to the intracellular concentration of iodide, which is considerably raised in hyperthyroidism, when the iodine trapping mechanism is enhanced. Occasionally prolonged ingestion of iodides has resulted in hypothyroidism and goitre formation. ${ }^{2}$ Patients who have previously received radio-iodine therapy or who have chronic thyroiditis appear to be particularly prone to iodide induced hypothyroidism. ${ }^{3}$

In contrast, iodide administration may also induce hyperthyroidism. The Jod-Basedow phenomenon has been clearly confirmed in recent years by workers in Tasmania ${ }^{4}$ after iodation of bread in an iodine-deficient area. Hyperthyroidism induced by iodide has also occurred in areas of iodine sufficiency. Vagenakis ${ }^{5}$ in Boston described four patients with nodular goitre without evidence of iodine deficiency. Iodide ingestion resulted in prolonged hyperthyroidism.

The mechanism of hyperthyroidism after a large dose of iodine remains unknown, though the normal homoeostatic regulation of thyroid function appears to be ineffective. This could be due to the presence of autonomously functioning nodules, independent of the action of thyroid stimulating hormone, which can increase the hormone synthesis in the presence of excess iodide.

${ }^{1}$ Blum, M., et al., New England fournal of Medicine, 1974, 291, 24.

2 Harrison, M. T., Alexander, W. D., and Harden, R. McG., Lancet, 1963, $2,1238$.

3 Braverman, L. E., Woeben, K. A., and Ingbar, S. H., New England fournal of Medicine, 1969, 281, 816.

4 Stevart, J. C., et al., Australian and New Zealand fournal of Medicine, $1971,3,203$.

5 Vagenakis, A. G., et al., New England fournal of Medicine, 1969, 287, 816.

Royal Albert Edward Infirmary, Wigan

B. J. FAIRHURST, M.D., F.R.C.P., Consultant Physician

N. NAQVI, M.B., B.S., Registrar in General Medicine

\section{Serum Lipids and Lipoproteins in Children with Kwashiorkor}

Though disorders of lipid metabolism have been described in kwashiorkor, ${ }^{1}$ controversy still exists about their exact nature. Inconsistencies may be due to differences in methodology as well as geographical variations in the patterns of kwashiorkor. They suggest the need for further investigations if only to attempt the clarification of the pathophysiology of some striking aspects of the diseasefor example, the extreme cerebral lethargy of kwashiorkor children and the enlarged fatty liver often found at necropsy. We have examined the concentrations of serum lipids, albumin, and total proteins in Nigerian children with florid kwashiorkor when admitted to hospital and before treatment.

\section{Methods and Results}

Investigations were carried out on 19 consecutive children, aged from 8 to 30 months, presenting with oedema, hepatomegaly, dermatoses, and cerebral lethargy. They were bled while fasting on the morning after admission. Ten healthy children of similar ages admitted for minor surgical procedures 